DEPÓSITO LEGAL ZU2020000153

Esta publicación científica en formato digital

es continuidad de la revista impresa

ISSN 0041-8811

E-ISSN 2665-0428

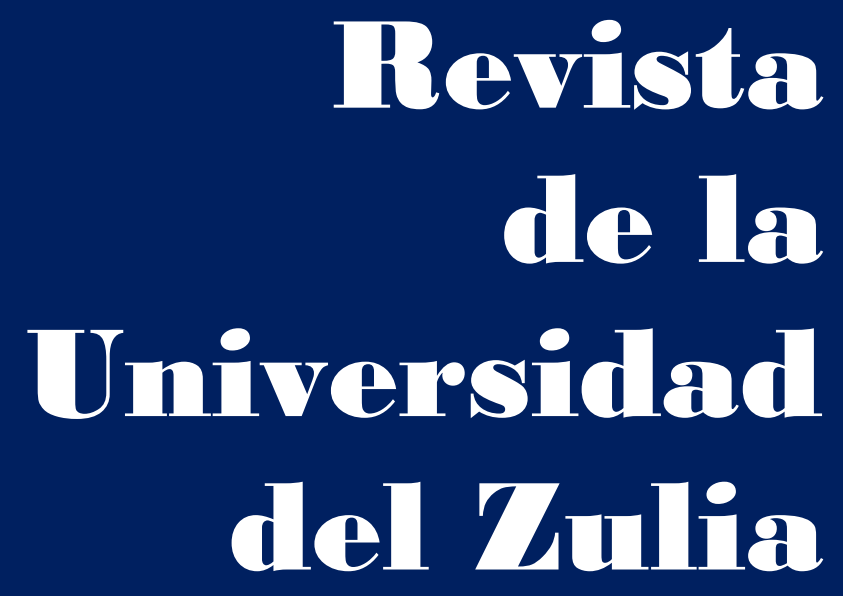

Fundada en 1947

por el Dr. Jesús Emrique Lossada

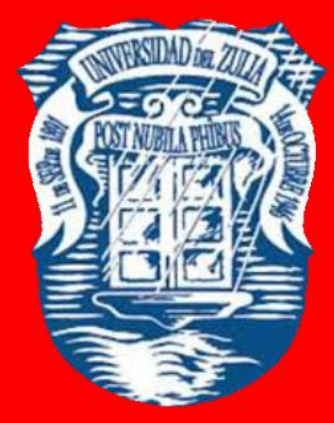

Ciencias

Sociales

y Arte

Año $12 \quad N^{\circ} 34$

Septiembre - Diciembre 2021

Tercera Época

Maracaibo-Veneruela 


\title{
The images of the russian ballet in the Fine Arts of the late XIX and early XX century
}

\author{
Tatiana V. Portnova *
}

\begin{abstract}
The purpose of the study is to analyze various interpretations of the theme of ballet in the context of creating an artistic image taking into account the specific characteristics of various arts on the factual visual material of the late nineteenth - early twentieth century. Methodology: 1) Search method, which allowed to reveal in museums and private collections, works of art dedicated to ballet of the period under consideration; 2) Historical and tipological method, which helped to group the works according to the thematic principle, to determine the degree of their value in the process of the creative work of the artist; 3) Method of stylistic analysis, which allowed to track the structural changes in the images created, the evolution of the creative method of the artist. Main findings: The nature of pictorial foundations in choreography is explored; the artistic pursuits and the various decisions in the masterpieces of graphics, painting and sculpture, dedicated to the ballet theatre and mostly connected with "The Russian Seasons" by S. Diaghilev; the main iconographic principles, the typology and the interpretation of ballet images are revealed.

KEYWORDS: ballet images; choreography; artistic interpretation; forms of interaction; dance.
\end{abstract}

*Doctor of Arts, Professor of the Department of "The Art of a Choreographer", Institute of the Slavic Culture, Art Criticism Department of the Art Institute, The Russian State University of A.N. Kosygin. ORCID: http://orcid.org/0000-0002-4221-3923. E-mail: infotatiana-p@mail.ru 


\section{Las imágenes del ballet ruso en las Bellas Artes de finales del siglo XIX y principios del XX}

RESUMEN

El propósito del estudio es analizar varias interpretaciones del tema del ballet en el contexto de la creación de una imagen artística teniendo en cuenta las características específicas de varias artes sobre el material visual fáctico de finales del siglo XIX - principios del XX. Metodología:l) Método de búsqueda, que permitió revelar en museos y colecciones privadas, obras de arte dedicadas al ballet del período considerado; 2) Método histórico y tipológico, que ayudó a agrupar las obras según el principio temático, para determinar el grado de su valor en el proceso de la obra creativa del artista; 3) Método de análisis estilístico, que permitió rastrear los cambios estructurales en las imágenes creadas, la evolución del método creativo del artista. Principales hallazgos: Se explora la naturaleza de los fundamentos pictóricos en la coreografía; las búsquedas artísticas y las diversas decisiones en las obras maestras de la gráfica, la pintura y la escultura, dedicadas al teatro de ballet y en su mayoría conectadas con "Las estaciones rusas" de S. Diaghilev; se revelan los principales principios iconográficos, la tipología y la interpretación de las imágenes de ballet.

PALABRAS CLAVE: imágenes de ballet; coreografía; interpretación artística; formas de interacción; danza.

Introduction

The Problems of choreography, which on the brink of the XIX_XX centuries were always standing apart from the art's great way, now become the subject of the liveliest and the most interested discussions and disputes. The classical dance, which was figuratively named by the ballet critic V. Svetlov as "A Cinderella, who was waiting for her prince in vain, who'd have found her pink satin boot and recognized her as the outstanding one among the equals" (Svetlov, 1911), at the time of the arts' brilliant rise makes it one of the most important factors of the cultural life. The ballet theater turned into a center, most of the creative intelligent people are gathered around and mostly all the head painters were associated with: K.A. Korovin, A.N. Benois, L.S. Bakst, M. Dobuzhinsky, S. Y. Sudeyikin, N. K. Roerich, B. I. Anisfeld. The role of the artist's concept in the play has changed with their appearance. From now, the painter became a choreographer's co-author, who prompted, sometimes dictated the choice of the expressive means to the painter, and, moreover, "interrupted" his plastic thinking. There is a striving for the music's harmonious unity in the ballet performances, in 
the dance and visual decisions. When E. Surits was writing about the fact, that in "The Russian Ballet" was seen much more than a choreographic theater, she was right. It became an expression of the new aesthetics, which included the new ballet forms, the new music and new painting; became an "aesthetic system", which has an impact on a wide range of cultural areas" (Surits, 1959). However, in addition to the theatrical and decorative art, whose place is already rather clearly determined by the criticism, at the crossroads of the two phenomena, a number of reforms was carried out by M. Fokin, A. Gorsky, A. Pavlova, T. Karsavin, V. Nijinsky, who has raised the ballet's level to a new quality; on the brink of the century the intensive development of the major fine arts drew the boarders of a new, little-researched theme, which was associated with the works of easel character and dedicated to the Russian ballet.

The picturesque canvases, the graphic sheets, the sculptural little figures, depicting the famous ballet dancers give a rich base for thinking over the dance art's subject, despite being scattered throughout the various private art collections, still outside the zone of the close attention. No doubt, the reason for the creating of works dedicated to the ballet was the ballet itself, as the performances lured so much attention to the artists' work, that their theatrical work stopped to be treated like an accidental phenomenon (Pastori, 2017). On the other hand, the artistic creativity was developed in the time of the era's mainstream and naturally reflected its most characteristic processes. On the brink of the century, the artistic life's creative atmosphere itself was distinguished by the breadth of the interests, and the desire to find the new aesthetic criteria of time caused the appearance of such a phenomenon as "ballet". The constant search for the poetic content, which doesn't appear in the surroundings, the artists find in the ballet as in the kind of art, which has a very specific language, as if it was closed in its aesthetic sphere and in fundamental contrary to everything ordinary.

Ideals of the ballet are the harmony and the beauty of the human body, which are expressed in the endless Harlequins and Colombines, in motifs of dance and plastic poses, is a certain cultural and aesthetic rule in the masters' biography of such a significant, but brief artistic period.

The plastic - visual features of the visual arts, which are graphics, painting, sculpture and ballet, determined the boundaries and the possibilities of their interaction, in which the 
corporeality and the materiality are expressed most clearly and visibly. The generality of the artist's and the choreographer's creative processes is obvious, which create the visible images of the play and the work of art, although the work of art is created outside the visual view, but the dance is being performed in front of the audience. The desire of artists to communicate with a mass audience actively and their inclination to the creation of a spectacular-saturated image, which can influence the viewer with a special emotionality's measure - all these things allow us to notice a strong closeness between them. The fine arts and the ballet have a lack of words, which is also the common feature of the connection between them; they use the similar expressive means to create an artistic image. The ballet lives in an obvious communication with the painting, the sculpture and the graphics, it experiences their influence and it also influences them. The choreography uses the elements of the fine arts - the color, the plastic sculpture, the lighting effect, and, in their turn, the masters of the fine arts are eager to capture the beauty of the ballet art, because the dance lives only while being performed, but the painting and sculpture can be inherited by the descendants.

To sum up, it was the closeness of the plastic arts that attracted the artists to the ballet, which could interact and enrich each other in the historical context of the time, inspire the hopes for a truly creative co-authorship. It may seem that the artist sets too limited frames and refers to the iconographic material, associated with the dance's fixation and often with the image of an artist, despite the fact that there are a lot of dance's shades, but there is only one the flesh and appearance of the image. Nevertheless, the semantics of the ballet theme in the artistic culture on the brick of the XIX-XX centuries is multifaced, it unites the masters who has the different artistic style, colorful palette, favorite compositional methods of the image building and the approaches to the theme's embodiment.

The searches of the artists in the portrait are mostly connected with the psychological aspect and the study of the ballet artists' personality. The short-term sketch can grasp the instant state of the ballet motion and can interfere into the movement mechanism of the classical dance. The sculptural material, due to its plastic features, can perfectly express the pantomime side of the dance, and the picturesque canvas or watercolor and pastel sheets convey all the beauty, all the festivity of the stage performance and its underside - the everyday life of the ballet. In a huge kaleidoscope of the graphic, pictorial and sculptural 
works, one sees not just a creative chaos, but also his own way to interpret the images of the dance.

Therefore, the relevance of the historical and art analysis of the epoch is due to the need to present the overall picture of the development of the ballet theme in the artistic culture of the late XIX - early XX centuries, the reconstruction of the general meaning and content of this heritage as an internally unified belief system that is being formed in the field of interaction of plastic arts. The degree of elaboration and relevance of the topic allows defining the purpose of the article: to analyze various interpretations of the ballet theme in the context of creating an artistic image taking into account the specifics of various arts on the factual visual material of the late XIX - early XX centuries.

\section{Review of literature}

There are numerous publications on the problem posed. The book by M. Fokin "Against the Current", which has already acquired the status of a monument to choreographer's thought, contains valuable comments on the art of Russian ballet itself. The author masterfully combines a description of his choreographic productions, historical facts and a careful analysis of the changes that have occurred, bringing them into the context of the book (Fokin, 1981). The book of the famous ballerina "Russian Seasons" T. Karsavin also set out in the genre of memories (Karsavin, 2017). Other publications characterize the era of the Silver Age and the activities of the enterprise of S. Dyagilev (Bukina, 2014; Katysheva, 2018; Dolgova, 2017; Järvinen, 2010; Järvinen, 2008; Krasavchenko, 2019; Mildon, 2013; Rabinowitz, 2009), the sphere of artistic design of ballets is casually affected only in some books (Scheyen, 2017; Fedorovsky, 2003; Pritchard and Marsh, 2013; Pritchard, 2009). The "borderline" concepts of art synthesis characteristic of this time are covered in articles by a number of authors (Azizyan, 2006; Butsan, 2012; Kiseeva, 2012).Interesting material can be gathered from publications analyzing individual performances and performance skills of ballet dancers (Charles, 1988; Farfan, 2008; Veroli, 2014). In the specified period, Russian ballet was part of the problem field of world art, occupying a leading place. Art exhibitions were regularly held and Sotheby's catalogs were printed, on the materials of which the visual interpretation of ballet images can be presented, but these works are usually not were the works of Russian artists (Roland, 2010; Sarah, 1990). The ballet images in Russian visual art have not been studied and scientifically developed, art critic literature only occasionally 
touches on some of the work of the easel artists on images of ballet, mainly masters, whose work has been studied (Davydova, 2015; Devereux, 1997; Golubev, 2017; Golubev, 2016). However, the ballet image as a subject of independent study even in these editions is not the main one. These works do not cover the whole range of existing graphic material and do not pose scientific problems (iconography, typology, interpretation, dynamics, style correlation), bypassing them with silence or characterizing them superficially.

\section{Methods}

The methodological basis of this study are:

-search method, which allowed to reveal in museum collections and private collections works of art devoted to the ballet of the period under consideration;

-historical and typological method, which helped to group the works according to the thematic principle, to determine the degree of their value in the process of the artist's creative work;

-method of stylistic analysis, which allowed to trace the structural changes in the created images, the evolution of the creative method of the artist.

\section{Results}

3.1. The dance as a reflection in the retrospective of the artists "The World of Art" The motives of the ballet are often found in the paintings of the graphic artists. "The World of Art" is one of the topics where the beauty is an area for the lyrical expression of the artists. The ballet is an ideal art for the embodiment of their artistic concept. It sees something consonant with their joys and sorrows; there are the moments of the complete spiritual rapprochement in it. As if they were afraid of the reality, of its rigidity and its daily routine, the "miriskusniki" tried to escape into the weirdness of the choreographic plot, in its infinity fantastic spaces. In the legends and tales of the romantic ballet, they often found the material for their compositions. In "The Ballet Pastors" and "The Apotheosis" (SRM, RAM) by S. Sudeyikin, in "The Ballets" by K. Somov there is an expression of the essence of one of the romantic trends. An escape from the reality in a world of dreams and fantasies. A.A. Evreinova remembered: "The Pierrots, the Harlequins, the crafty Colombines, depicted ... in a merry dance, almost hypnotically took me away from the unbearable reality ... When I woke 
up in the morning, I liked to say hello to my new tenants over the bed - the Sudeyikin'scolorful heroes of the Harlequin" (Evreinova, 1956).

The ballet compositions by S. Sudeyikin, which are so reminiscent of the paintings' atmosphere by A. Watto and F. Bushe, are constructed as a stage space on which a dreamyphantom and dramatized action unfolds, where the characters live like in poems in a bliss of the insanity and disconnection. It is not an accident that the theme of the landscape arises with the images of male and female dancers, living in a full harmony with the surroundings. The nature is as a sensitive tuning fork in the works of the artist which meets the subtlest spiritual movements of a man. However, the landscape of Sudeyikin performs not only a supporting role. The originality of the artist's works is that nature enters them together with the man as the main hero. They complement each other, gravitate toward a certain harmony, and exist as a single valuable picture of the world. The motives of the lake with the floating swans often take place in the ballets, managed by Sudeyikin; they bring a poetic stream into them, they carry out the main theme of the dance's beauty and harmony. The softness in the performance of the figures and the background is provided by the changeable states of the nature (morning or evening) and dissolves the contours in the airy and coldish haze; the pinkish-bluish pastel color gives a matt, slightly faded tone, gives a rise to a sad melancholic mood, a poetic understatement of the images, their desire, which is expressed better in a desolation than in standing out. All the picturesque means chosen by the artist create a slow rhythm of the dance, silently gliding movements of the heroes, which, with a little rustle, exist as if they were on the verge of the reality and the fiction.

"The Russian Ballet" (1930) called "Sylphide" (AMO) by K. Somov - these watercolor sheets, as well as the works by Sudeyikin, are interesting not only with the topic's image, but the artistic world outlook, expressed in them as expressed and formed by the past-time distance. That's why the topic of these works is not the ballet itself, but mostly an emotional memory of it. The dreamily enlightened image of the Sylphide dates us back to engravings of the XIX century, to the images of Taglioni and Istomina, to the romantic direction of that time in the dance. But the fundamental novelty of Somov's works lies in anything else, mostly in a striving to see the ballet plot - not unambiguously, not straightforwardly, but in the unity of the diverse qualities. Here Somov is interested not only by a combination of the fictional and the real, but by the borderline between the reality and the fantasy, that fragile 
moment when the dance becomes the reality. The dimness of the quieted hall creates a sense of a mystery, the dance flows under the poetic sound of music. Only for a moment the romantic heroes opened up their destinies for the audience, having the opportunity to live their only life quickly and go into the world of the ordinary prose forever. Somov could show the birth of the ballet performance gracefully, with a number of the direct observations, preserving a sense of mystery and a theatrical magic.

The echoes of the ballet theme in a different, much more subtle and complex refraction can be seen in the "Harlequins", "the Italian comedies" by A. Benois, "Columbines", "Harlequins", "Dames" and "Pieros" by K. Somov, where not a dance itself is shown, but its features, which have their appearance in such a dance. The ability to express a thought plasticly is the thing that distinguishes the ballet artist on stage. So, the works of Somov and Benois reveal the conditional world of the masquerade, convey the artistic expressiveness of the choreography, which consists of the plastic poses, the facial expressions and the gestures. By transferring the organic fusion of these elements in the image of their heroes, the artists persistently search for the ways to discover their most intimate soul depths, as in the forms and the postures of the man, as in the ballet performance, the inner state of the images is revealed.

The other side has the characteristic tendency along with the indirect form of the dance's image on the brink of the century: the theatricalization of the easel painting itself, the introduction of the scenic moments to it. Just as the choreographer deals with the compositional arrangement of the artists on stage, the main performers and the corps de ballet, the artists of "The World of Art" depict the solemn royal walks, the peacefully moving ceremonies of the royal processions, decide the space as a scenic platform bounded by the scenes, and the figures are distributed according to the laws of beauty and harmony.

Another feature which is manifested in such works is attributed to the artists building the multi-figure compositions, as if they were in the spirit of the former searches made by M. Petipa and L. Ivanov. It sounds like nostalgia, like an idealization of everything that has been left behind. They attach the fundamental importance to the structural similarity between the internal organization of a separate stage of the ballet performance and the figurative system of their paintings.

3.2. The sketches of the ballet costumes in the stage design of the dance 
Another category of the ballet images' creation can relate to the works which are connected with the ballet performance's work on the design, in which the problem of the costume is solved in a motion and is inseparably connected with the stage im age, that's why it touches the topic directly under consideration. The art of L.S. Bakst in this respect is the brightest example. Undoubtedly, Bakst was one of the most consistent artists-innovators of the ballet troupe by S. Diaghilev, in whose images the role of the reformation of the ballet costume is especially noticeable, as one of the most important achievements of the Fokin ballet. The Bakst's costume is always mobile, he accurately conveys the specificity of the ballet art, the basis of which is the movement. His characters are unstable in the clear relief of their poses, in the languishing and in the melodious plastic of an almost physically sensed body, the inviting power of the ballet image is completed. V.Svetlov characterized it as the following: "The pleasure you get from the performance is strong because its beauty does not remain fixed and frozen, but changes and moves every minute. The weaving and unweaving groups of the male and female dancers, the constantly new and changeable contrasts and the rapprochement of the shades formed by their costumes - all this swaying movement, the flow of flowers are combined and settled with the most refined art, precise and at the same time bold" (Svetlov, 1911). It is easy to see that in most of the sketches the characters have a foot only on the one leg: "Harlequin" - the sketch of the ballet's costume "The Carnival" (1910), "The Silver Negro" (MIS), "The Odalisque" (collected abroad), "The Young Indian" (1910, private collection of Paris) - all the costumes' sketches for a ballet "Scheherazade," "St. Sebastian" (1911, AMO), etc. Emphasizing the main gravity of the body on the supporting leg, in the different versions bizarrely bending the other, from which the movement goes on, across the figure, hands and finally the head, the artist allows to understand the whole complex apparatus of the classical dance. His "vertical" costumes are as the exotic plants, starting their movement from the toe of the supporting leg, growing gradually up. There is a sudden feeling that Bakst doesn't compose the ballet costume in his imagination and then puts it on the dancer, but, on the contrary, he sets the task as the outline to capture the character of the dancing figure immediately, and, proceeding from the movement which was slightly rethought by his imagination, he simultaneously thinks over the costume, because his costumes are not partial, do not inspire us with the feeling of a long work on them and cause a feeling of a direct sketch from the nature. Bakst does not use the complicated pictorial 
transitions, but works as a local spot, because the transmission of the chiaroscuro heavies stops the movement. The elastic and musical line outlines the figure of Harlequin's costume in the ballet "Carnival" (1910). Throughout the refined, elegant movement, Bakst creates an image of an exquisitely inviting hero. Softly, like an inaudible breeze, smiling at us, standing on the pointe shoes of T. Karsavin's "Bride" -this is the sketch of the costume for the ballet "The Blue God" (1932, SCTM).

With all the ease of the transmitted movement, unlike "Harlequin", the specific shape of the ballerina can be guessed here. For Bakst, it is important not just to develop the look of a costume, it is equally important to create a ballet image of a specific artist in this costume. Another series of Bakst's costumes are suits, the movement of which develops not only one supporting leg, but both, or rather they do not have the support at all, but hang in the air; it is a reception that gives the artist the lightness and the weightlessness of the classical dance. "Kiarina" is the sketch of the costume for the ballet "The Carnival" (1910, SPMA), "The Firebird" is the sketch of the costume for the ballet "The Firebird" (1916, MMA), etc; or the costumes, that find the scope and breadth, when the movement is transferred to them. Their compositional drawing develops the expressive, flight movements, as the most vividly expressing the elements of the very ballet movement, the floating. These are such like: "Echo", "Beotijka", "Two Boeotiki" - these are the costumes for the ballet "Narcissus" (1911, SPMA, Lobanov-Rostovsky's Collection, the USA). Let's look at the way Bakst portrays the movement. It's easy to see that his characters dance in a certain kind of the ballet of otherness, as if they feel the charm of the process. The exquisite head tilt, the half-opened eyes, the developing folds of clothes, the flying hair, a wave of hands with the beautifully curved brushes - all this in a true found and delicately sensed movement conveys the pulse of the dance itself, the very atmosphere of the artists' stay in the image. In the costumes of Bakst, it is difficult to catch the certain ballet movements, his dance is rather antique, coming from the school of A. Duncan. This is dictated, of course, by the content of the ballet itself, by the Fokin reforms of the emancipation of the body, but I still think that by its ornamental character, the sheet organization, and the interpretation of the draperies resembling the modernity, the goal of Bakst is to show the human body in some of the most beautiful and whimsical movements. Moreover, such provisions and angles cannot be obtained with the accurate reproduction of the classical ballet, since its poses and positions have rather strict 
rules. It can be assumed that Bakst intentionally leaves him to create the sheet of the smooth rhythmic elements. This is largely promoted by developing the surface of the sheet draperies. Twisting on the sheet several times, intertwining the bodies of the dancers, they further strengthen the sense of the flightiness of the dance. Covering the watercolors with a local spot of costumes, Bakst does not use the color in bodies, but he applies hatching to show off more boldly the sculptured and carnal beauty of figures.

Thus, through his inherent stylization, Bakst extracts the inaudible music not only from the composite construction of an elegant figure of the bodies and the draperies, but from the thin watercolor constructions, sounding differently, depending on the nature of these constructions, sometimes subtly tender, sometimes bright and contrasting, in this way transferring the special style and intonation of the Fokin's ballet.

\subsection{The ballet as a performance and action in the format of the serial images}

The ballet in the works of V. Serov and Z. Serebryakova is a new step in the development of the ballet theme in the fine arts of the late XIX - early XX century. The deep knowledge of the depicted material, the adherence to the principles of the realistic art, the virtuous mastery of the embodiment of the ballet images that distinguish the works of Serov and Serebryakova, all this allow us to consider their searches in the ballet theme separately from the artists who were the members of the World of Art. Although Serov's images appeared in 1906-1910, and Serebryakova's only in the 1920s, many of the members of "miriskusniki" created the ballet works later than Serov, the analysis of the ballet heritage of these masters after the group "miriskusniki" wasn't based on the chronological principles. Serov and Serebryakova not only differ from the masters which were already considered - all the artists are not alike to each other - but they also differ typologically. They do not belong to another time, but their artistic thinking over the ballet image and its creative embodiment is different from the aesthetic principles and the stylistic forms of "miriskusniki." In the works of Serov and Serebryakova, the question of the reflection of the ballet theme in the visual arts is appropriate to be considered with the French artist E. Degas, who was the most consistent and vivid researcher of it. This should not mean that the artist copied or simply borrowed something from Degas like a plot for the compositions, but it is indisputable that his art was studied and known. "Now there is a big exhibition here by Degas, my favorite artist, and I will certainly go" (Serebryakova, 1987) - writes Z. Serebryakova. "The Blue 


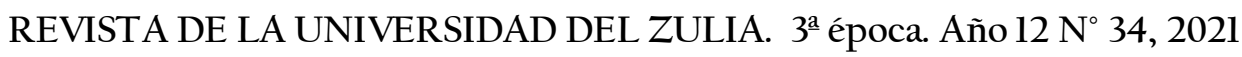

Tatiana V. Portnova // The images of the russian ballet in the Fine Arts... 631-650

DOI: http://dx.doi.org/10.46925//rdluz.34.34

Ballerinas" (SAM) by Serebryakova force to recall the images of "The Blue Dancers" (SPMA) by Degas, the association with which arises not from the same sound of the names of these works, but primarily on the plastic and color of their decisive method. In the rhythm of the corsage and packs, in the kaleidoscope of the naked spins and hands, illuminated by the bright light, and therefore absorbing all the color reflexes from the environment; in the pure pulsating spots of color from the intensely darkness in the shade and bright, almost bleached in the light, merging one into the whole - with the help of all these - the main emotional sound of the Serebryakova's images and Degas is concentrated.

The ballet theme in the works of Serov artists and sometimes by Serebryakova is developed in the direction of the ballet portrait image. But if the portraits of Serebryakova are represented by the young and, sometimes, not well-known artists of the Petrograd corpsde-ballet or the children in the ballet costumes, Serov created only the portraits of the eminent figures of the Russian choreographic school: A. Pavlova, T. Karsavin, V. Nijinsky, I. Rubinshtein, M. Fokin. The portrait images by Serebryakova depict the costume image, do not differ in the depth of the characteristics; the faces of the models seem to be idealized, but at the same time they retain the portrait features. The elusive and somewhat superficial spirituality in these portraits appears as in a hidden way behind an external theatrical mask, when the underlined turn or the inclination of the head, a flirtatious look here is quite natural, as well as during a concert performance. These cute and adorable models, which $Z$. Serebryakova often recalled, seem to be like each other, they have the features of the harmonic perfection's single theme of the ballet artist's appearance.

In the images of Serov, the idea of an individual personality, its highest value for the culture acquires the exceptional importance and becomes the starting point in his search. Serov avoids the complicated and detailed compositions, which are not uncommon in the works of "miriskuniki" and Serebryakova. Like L. Bakst (portrait of A. Pavlova in 1908, A. Duncan in 1908, V. Tsukki in 1917) and M. Dobuzhinsky (numerous pencil portraits of T. Karsavin, 1914-1923), he can find and put forward the close-up expressive artistic details in the guise of an artist, but he is the only to know how to remain extremely laconic at the same time. Impressing the artists during the performances of "The Russian Seasons", organized by S. Diaghilev, in the moments between the rehearsals, he doesn't only copy the model, but also creatively reinterprets, seeking in each ballet artist a characteristic and lasting. In his pencil 
sketches, there is not even a hint of an image of the scene, but the sensation of where it occurs is; Serov managed to show the externally poetic images so true, as well as the intense atmosphere of the rehearsals, the daily routine of the ballet. Wiping the perspiration from her face, T. Karsavin stopped with a towel in her hand - "The Portrait of T. Karsavin" (1909). And Pavlova froze in a motionless pose, still comprehending her role - "The Portrait of A. Pavlova" (1909, the State Tretyakov Gallery). V. Nizhinsky appeared in the hall, now he will enter the image and the class will begin - "The Portrait of V. Nijinsky (1909-1910, SPTM).

The ballet is the work - this theme sounds in the works of Serov. In this respect, it is close to the images of Degas. But with all the similarity of this aspect, the ballet in Serov's work and the ballet in Degas's works are still different in the ways of reading the ballet theme. Serov painted portraits of the ballet artists, and Degas painted the portraits of the ballet classes, varying in numerous the versions of the exercises at the machine and in the middle of the hall, the rehearsals on stage, which only occasionally turns to the motive of the stage performance. The ballet in the understanding of Serov is expressed through a specific and outstanding image of the ballet artist. The ballet in the work of Degas is developed from the small participants, starting their creative path to the experienced ballerinas. For Degas, the personality of the dancers is not important, even when he depicts a prima ballerina on stage, he does not give her the name. The ballet as a group of female attendants is devoted to the only business - to the dance, when the personal destinies of dancers remain outside the ballet class, outside the stage, finally, outside the attention of the artist. The ballet in First of all, Degas' work is a systematic hard and selfless work, which requires a tremendous strain of the physical strength. Serov's work is spiritual, it is more the work of creative thought over the role, so that the spiritual work will find the expression in the physical beauty of the dance. Unlike Serov, the ballet works of Degas show the work of the ballet movement, sometimes habitual, repeated, memorized by heart, mechanical, not requiring the intensive work of thought, but it is important, because it is a very hard work - this is the feature of this profession. In this respect, the ballet theme of Degas has more similarities with Serebryakova's theme. Her paintings vary and develop one main theme - the everyday life of dancers. Among the features of the ballet theme, Serebryakova includes a new feature - an image of the multi-figured compositions in the interior. In the artists of "The World of Art", these were the paintings-spectacles and the paintings-performances. Serebryakova's theme 
of ballet is often solved in the interior of the theatrical lavatories, even for the first time, where the ballet dancers make up and prepare for the exit.

For the first time, Serebryakova, like Degas, gets behind the scenes, opens the door to the creative laboratory, where the ballet images are born, but the artistic image of Serebryakova and Degas dance goes in different ways, although in many works it almost coincides. The numerous dance classes of Degas are a world where there is no applause and colors, a miracle light of a searchlight, but there is a hall salty from the spilled sweat, a monotonous, black-n-white picture of the daily training. Serebryakova's ballet lavatories are also a workshop with the daily, habitual preparatory work to the performance, but the emotional mood of the artist's works anticipates a feeling of the celebration and beauty. The ballet is the work, this is the accent in the works of the both artists, but in Degas's works the ballet is an ugly routine, and in Serebryakova's ballet it is a poetic routine. In work, even if not as tense and complex as in the hall near the machine tool, but also necessary and important, they reveal their valuable qualities, receive the highest satisfaction of the Serebryakova's heroine. On the vertical and the horizontal formats: "The ballet lavatory. The snowflakes.The Nutcracker ballet" (1923, the Russian Museum), "The ballerinas in the restroom. The ballet "Paquita" (1922, collected by I. S. Zilberstein), "In the ballet restroom. The ballet "Fairy dolls", 1922, SCTM), "Girls - Sylphs. The ballet "Chopiniana" (collected by S.N. Serebryakov), etc., capturing the hours of preparation before going on stage, having the figures of only dressed and ready-made ballerinas employed in the first act, the artist seems to enjoy, drawing mentally the process of depicting the flexible ballet body in the finished image of the beauty and harmony.

The interest in the ballet theme on the brink of the century is not limited only to the work of the artists who were the members of "The World of Art", Serov and Serebryakova. The exhibitions, often organized by S. Diaghilev, were literally filled with works of the unknown artists dedicated to the Russian ballet. Here you can say the names: S. Sorin, M. Detoma, A. Mac and many others. It was an era that left behind a great spiritual legacy. The dancers and the choreographers: A. Pavlova, V. Nizhinsky, M. Fokin also created the works dedicated to the ballet in sculpture, graphics and painting. Their work in this area can be equated to the work of the professional artists. From this point of view, they prove to be of a 
REVISTA DE LA UNIVERSIDAD DEL ZULIA. 3a época. Año 12 N³4, 2021

Tatiana V. Portnova // The images of the russian ballet in the Fine Arts... 631-650

DOI: http://dx.doi.org/10.46925//rdluz.34.34

fundamental interest, since their authors look at the problems of the ballet with their own eyes and through the other art.

\subsection{The ballet in sculptural interpretation and category of plasticity}

The ballet at the end of the XIX century - the beginning of the XX century has found the most vivid embodiment not only in the painting and graphics, but also in the sculptural plastic, because it has its own, special, only inherent capabilities that distinguish its language from the language of the other fine arts. It contains the huge resources for developing the ideas for the ballet image. Of all the theatrical arts, the ballet is the closest to the sculpture, because the means of the artistic expressiveness both in ballet and in sculpture is the plastic beginning. The plastic category is the original category of both arts. It provides an opportunity to view the turn, the incline of the figures, the rhythm of the movement, talking to the viewer exclusively with the language of the plastic of the human body, always expressive and spiritual. Plastic is inexhaustible, it can be deepened indefinitely, it contains a continuous vibration of the movement of forms, lines, volumes. Through the movement in the ballet and in the sculpture, the mental state of the model is revealed, it mainly becomes a means of recreating the spiritual atmosphere of the artistic image.

O. Roden in his article "The Renaissance of The Dance" said: "From the plastics' point of view, there is something to learn from these artists and draw from their art a lesson of grace" (Roden, 1912). In addition, the sculpture and ballet have a remarkable ability to capture the beauty of the movement in a voluminous and, therefore, in a particularly clear and convincing form. If you look at the creative heritage of the masters, you can say with a certainty that the sculptural works that captured the dance were solved with an understanding of the possibilities inherent in this art form. Just as in the painting, there are several genre lines in the sculpture treating the ballet theme. This are the portrait images, and the image of the figure in the growth at the time of the dance, and the imprint of the artist during the rest. In the terms of the spiritual interpretation of the ballet image, the emotionally-romantic direction is especially interesting. Like for "miriskusniki", for sculptors it was an uncharted world of poetry, in which the dance seemed to approach its natural language due to its embodiment in the material and received a sense of reality almost to the touch. The images of the romantic ballet in sculpture also became a favorite theme for the 
embodiment, because they are endowed with fantasy, mystic moods, the ability to transform into the rank of a wonderful idea by nature.

The ballet images of P. Trubetskoi, M. Vrubel, S. Erzya (Nefedov) may not be the most ambitious in their heritage, but they reveal many of the ideological and creative features of the artists, their inner thought' sound. One can trace a certain similarity between the figurative principles of the works of these artists. They coincide in the main motives of creativity, in the interpretation of the ballet theme there is a combination of the fictional and the real. In the sculpture "The Dancer. Fantasy"(SRM), Vrubel was interested in the difficult turn of the head of a fantastic dancer at the moment of dancing. The quivering brush strokes are felt on the surface of the sculpture, the plaster itself prompts the movement of the masses, the appearance of the image. He seems to be born from the elements of the material and acquires a refined, beautiful form. The sculptural material plays an important role here and allows us to talk about the equal importance of both visual and tactile sensations. In the works of Trubetskoi: "A. Pavlova" (collected abroad),"The Dancer"(SCTM),"The Dancer"(RAM), the comprehension of the image of the dance goes not so much through the image as through the dynamics of the technique, the intonation, the style of modeling. Behind the texture of the material, the movement of the stack sees the inner mood, the perception of the world, the work of the artist's thought. Contemplation of dance, like the movements of ballet pas, generates an instant state in the sensitive soul of Vrubel and Trubetskoi, which they are trying to show. The impressionist stylistics creates the subtle nuances of the movements of the ballet, as if not finished, being in their transitional hypostasis, halted at half-expression. Thus, the image of A. Pavlova in the work of Trubetskoi seems to live in a kind of dream, floating along the current, instinctively choosing movements where there is no need to make efforts to fulfill them, exists as a dream, a dream that quickly escapes the shadow, magically captivating and unattainable. The indirect movements of the sculptural forms in the "Dancer" of Vrubel form an endless stream of the magical-mystical dance. Even more unexpected are the ballet sculptures made of wood by S. Erzya. They stand out against the background of the above works, they are distinguished by an unconventional creative vision, defined by a philosophical artistic approach to the theme of dance. His "Ballerinas" are painted in the romantic tones and in this they are similar to the images of Vrubel and Trubetskoi. 
REVISTA DE LA UNIVERSIDAD DEL ZULIA. 3a época. Año 12 N³4, 2021

Tatiana V. Portnova // The images of the russian ballet in the Fine Arts... 631-650

DOI: http://dx.doi.org/10.46925//rdluz.34.34

However, unlike the improvisational movements of their dancers, the Erzya ballerinas dem onstrate a certain movement, it is always the final point of the movement, its conclusion or beginning. Representing the ballet dancers A.Pavlova, M.Kseshinskaya in a pose called arabesque, Trubetskoi gives them a certain erasure: this is not arabesques, but a halfarabesque, as if a moment's reflection, while Erzya's "Ballerina" of 1930 (MRAM) presents an extremely clear scheme, a clear silhouette of this posture, its duration and completeness. The static category of the sculpture and the dynamic form of dance are combined in the synthetic structure of the plastic image reflecting the corporeality associated with the "sensation of the movement" or the perception of the information through the movement.

You can refer to a few names of sculptors and many their sculptural works. However, within the limits of our article, we do not have the opportunity for a detailed analysis of the problems of a selected topic containing the large and complicated questions and will confine ourselves to what has been said.

\section{Conclusion}

Having made a brief excursion into the history of the ballet in the fine arts, we can build a typology of artistic images that was formed at the turn of the XIX - XX centuries, get an idea of the masters and to some extent recreate the picture of the development of the topic, delineate the broad boundaries of the searches, and to reveal the problems that worried artists and were solved by them while they were working on them. There were the works before us, which were created primarily by the decorators to the works of the masters who worked directly on the ballet theme, from the dance motives to the ballet images depicting the outstanding masters of the Russian choreography, from the sketches of the artists "The World of Art", who anticipated the ballet as a theme in the visual arts to the actual ballet images in sculpture, which immortalized him. The fleeting moments, stopped by the artists, preserve for us the perennial images of Russian choreography, thus prolonging their "scenic" life. The multicomponent structure of synthesis determines the difference in the flow of thought and activity within the forms of interaction between the plastic arts. A deep essential analysis of the master's pictorial, graphic and sculptural works made it possible to reach the level of stylistic generalizations, which is a significant step in the theoretical study and understanding of the creative heritage of the masters who turned to capturing Russian ballet. The special perspectives of the material studies allowed us to consider the artistic 


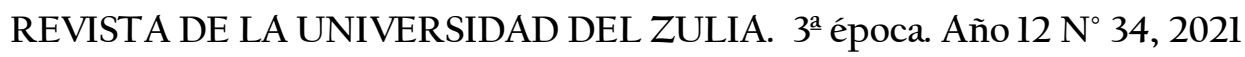

Tatiana V. Portnova // The images of the russian ballet in the Fine Arts... 631-650

DOI: http://dx.doi.org/10.46925//rdluz.34.34

achievements not only in the traditional art criterion, but also in a multidimensional cultural field, an advanced picture of the spiritual interaction of artists and choreographers of one epoch.

The analytical work carried out allows us to conclude that in the Russian art of the late XIX-early XX centuries, there are the following trends in the image of dance:

- The appearance of the first one is due to the new idea of dance, which is relevant for the Silver Age, as the embodiment of harmony, aesthetics of the perception of the world by artists of the "World of Art", Ballet imagery is organically interwoven into the poetic fabric of graphics and painting, forming a new type of synthetic artwork that combines the techniques of fine and ballet art;

- The second trend acts as a realistic interpretation of ballet images, directly a fullscale image of it. Portrait images that occupy a large place in this group of works convey the nuances of the psychological and artistic image;

- The third aspect associated with the embodiment of sculptural fixation of the dance allows us to show its volume-tectonic structure. The dynamics of ballet with its implied theatrical expressiveness of gestures and movements often found a response in the works of masters who sought to convey a sense of its plastic equivalence with the help of sculptural materials and techniques.

In my study, I tried to show that the analysis of many works of art of the turn of the XIX-XX centuries without "connecting" the figurative system of an adjacent art form leads to the impoverishment of their internal content. The numerous works identified and collected together from the funds of museums and private collections, some of which are presented in this article, demonstrate a single figurative theme that develops into a diverse picture of creative aspirations, methods and technologies, which allowed it to maintain a leading position at the turn of the century. The main provisions of our research can be used in the process of art history and cultural studies of both fine and ballet art in a single space of the Silver Age era, and can also be included as auxiliary material in the educational course of students of creative specialties.

\section{References}

Azizyan, I.A. (2006). About the dialogue of arts of the Silver Age. Solov'evskieissledovaniya [Solov'ev studies], 12, 112-138. 


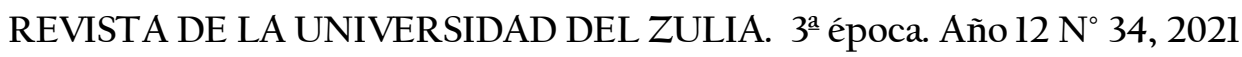

Tatiana V. Portnova // The images of the russian ballet in the Fine Arts... 631-650

DOI: http://dx.doi.org/10.46925//rdluz.34.34

Butsan, A.S. (2012). "Russian Seasons" by S.P. Dyagileva in the context of the synthesis of art. VestnikMoskovskogogosudarstvennogouniversiteta [Bulletin of Moscow State University], 5 (49), 86-89.

Bukina, T.V. (2014). "Russian Seasons" by S.P. Dyagileva: at the origins of Russian art management. VestnikAkademiirusskogobaletaimeni A.YA.Vaganovoj [Bulletin of the Russian Ballet Academy named after A.Ya. Vaganova], 4 (33), 94-103.

Charles, S. (1988). Mayer. Ida Rubinstein: A Twentieth-Century Cleopatra. Dance Research Journal, 2 (20), 33-5l.

Davydova, O.S. (2015). The Poetics of Images by Alexander Golovin. Iskusstvoznanie [Art History], 1-2, 368-395.

Devereux, T. (1997). Alexander Benois and the Russian Revolution. Dance Research: The Journal of the Society for Dance Research, 1(15), 58-78.

Dolgova, V.N. (2017). "Russian Seasons" in England: unknown pages. UchenyezapiskiOrlovskogogosudarstvennogouniversiteta[Scientific notes of Oryol State University], 2 (75), 26-30.

Evreinova, A.A. (1956). The Memories of Sudeyikin. RGALI.

Farfan, P. (2008). Man as Beast: Nijinsky's Faun. South Central Review, 1 (25), 74-92.

Fedorovsky, V.F. (2003). SergejDyagilev, ilizakulisnayaistoriyarusskogobaleta [Sergey Dyagilev, or Backstage History of Russian Ballet]. Moscow: Eksmo.

Fokin, M. (1981). Protivtecheniya: vospominaniyabaletmejstera: scenariiizamyslybaletov :stat'i, interv'yuipis'ma [Against the Current: Choreographer's Memories: Scenarios and Concepts of Ballets: Articles, Interviews, and Letters]. Leningrad.

Golubev, P.S. (2017). Reflexes of symbolism in the works of K.A. Somov 1900-1910's - Dom Burganova. Prostranstvokul'tury [Burganov House. The space of culture], 1(8), 165-177.

Golubev, P.S. (2016). The boundaries of genres in the art of K.A. Somov. Dom Burganova. Prostranstvokul'tury [Burganov House. The space of culture], 1, 99-118.

Järvinen, H. (2010). Failed Impressions: Diaghilev's Ballets Russes in America, 1916. Dance Research Journal, 2 (42), 77-108.

Järvinen, H. (2008). 'The Russian Barnum': Russian Opinions on Diaghilev's Ballets Russes, 1909-1914. Dance Research: The Journal of the Society for Dance Research, 1 (26), 18-41.

Karsavin, T.P. (2017). Teatral'nayaulica: Vospominaniya [Theater Street: Memories]. Moscow: Tsentrpoligraf. 
Katysheva, D.N. (2018). Novatorskieotkrytiyahoreografov v rossijskombaletnomteatre XX veka [Innovative discoveries of choreographers in the Russian ballet theater of the XX century]. Moscow: Manuscript.

Kiseeva, E.V. (2012). Performances of Russian ballet of the beginning of the 20th century as a synthetic whole. Mir nauki, kultury, obrazovaniya [World of Science, Culture, Education], 6 (37), 378-381.

Krasavchenko, T.N. (2019). Russian seasons of Dyagilev in the UK. Paradoxes of Cultural Interaction. Vestnikkul'turologii [Bulletin of Culturology], 1, 34-57.

Mildon, V.I. (2013) Silver Age or Russian Renaissance. Vestnikkulturologii [Bulletin of Culturology], 1 (64), 5-31.

Pastori, J.P. (2017). RenessansRusskogobaleta [Renaissance of the Russian Ballet]. Moscow: Paulsen.

Pritchard, J., Marsh, G. (2013). Diaghilev and the Golden Age of the Ballets Russes 1909-1929. London: V $\&$ A Publishing, London.

Pritchard, J. (2009). Serge Diaghilev's Ballets Russes-An Itinerary. Part II (1922-9). Dance Research: The Journal of the Society for Dance Research, 27 (2), 254-360

Rabinowitz, S.J. (2009). From the Other Shore: Russian Comment on Diaghilev's Ballets Russes. Dance Research: The Journal of the Society for Dance Research, 27 (1), 1-27.

Roden, O. (1912). The revival of the dance. The studio, 32-33, 8.

Roland, J. W. (2010). Archives of the Dance (23): John Milton and Ruth Neils Ward Collection at The Harvard Theatre Collection, Harvard University \& The Mikhail Larionov Archive at The State Tret'yakov Gallery, Moscow. Dance Research: The Journal of the Society for Dance Research, 28 (2), 218-235.

Sarah, C. (1990). Woodcock. Archives of the Dance: Later Dance Holdings of the Theatre Museum, London. Dance Research: The Journal of the Society for Dance Research, 8(1), 62-77.

Serebryakova, Z.E. (1987). Letters from Serebryakova Z.E. Paris (March 31,1937). Moscow.

Scheyen, Sh. (2017). SergejDyagilev. "Russkiesezonynavsegda" [Sergey Dyagilev. "Russian seasons forever"]. Moscow. ABC-Atticus.

Surits, E. (1959). The Russian Seasons. The Theater, 11, 80.

Svetlov, V. Y. (1911). The French criticism of the Russian ballet in the book: The modern ballet. St. Petersburg.

Veroli, P. (2014). Serge Lifar as a Dance Historian and the Myth of Russian Dance in "ZarubezhnaiaRossiia" (Russia Abroad) 1930-1940 Dance Research. The Journal of the Society for Dance Research, 32, (2), 105-143. 